- ORIGINAL ARTICLE Volume 9 Issue 12017

DOI: 10.21315/eimj2017.9.1.7

ARTICLE INFO

Submitted: $30-01-2017$ Accepted: 09-02-2017 Online: 31-03-2017

\section{Validation of Malay Version of Incontinence Praying Ability among Childbearing Women Who Attended Hospital Universiti Sains Malaysia}

\author{
Dariah Mohd Yusoff ${ }^{1}$, Yee Cheng Kueh ${ }^{2,3}$, Hanis Ismail' \\ Nyi Nyi Naing ${ }^{2}$ \\ ${ }^{1}$ School of Health Sciences, Universiti Sains Malaysia, 16150 Kubang \\ Kerian, Kelantan, Malaysia \\ ${ }^{2}$ Unit of Biostatistics and Research Methodology, School of Medical \\ Sciences, Universiti Sains Malaysia, 16150 Kubang Kerian, \\ Kelantan, Malaysia \\ ${ }^{3}$ Department of Psychiatry, School of Medical Sciences, Universiti \\ Sains Malaysia, 16150 Kubang Kerian, Kelantan, Malaysia
}

To cite this article: Dariah MY, Kueh YC, Hanis I, Naing NN. Validation of Malay version of incontinence praying ability among childbearing women who attended Hospital Universiti Sains Malaysia. Education in Medicine Journal. 2017; 9(1): 69-79. https://doi.org/10.21315/eimj2017.9.1.7

To link to this article: https://doi.org/10.21315/eimj2017.9.1.7

ABSTRACT

Objective: To determine the validity and reliability of Incontinence Praying Ability (I-PA) among Muslim childbearing-aged women. Methods: A cross sectional study was conducted among Muslim women under childbearing age attended clinics in a university teaching hospital. Two measures were used in the present study and there were I-PA and Incontinence Quality of Life (I-QoL). I-PA was developed in Malay language and its construct validity had not been explored. The questionnaires were handed to the Muslim women during their visit to the clinics in Hospital Universiti Sains Malaysia. Exploratory Factor Analysis (EFA) was conducted to determine the construct validity and the Cronbach's alpha was used to examine the internal consistency reliability of I-PA. Pearson correlation was used to examine the correlation between I-PA and the subscales of I-QoL. Validity was further supported if both scales were significantly correlated. Results: A total of 162 Muslim women completed and returned the questionnaires to the researchers. The mean age of participants was 32.4 $(\mathrm{SD}=5.87)$. Based on EFA result, all the 10 items of I-PA were remained in the model under one factor and no item deletion was required. The factor loadings were ranged from 0.70 to 0.91 . The internal consistency of I-PA was satisfactory with Cronbach's Alpha of 0.94. There were significant correlations between I-PA and I-QoL's subscales, ranged from 0.64 to 0.71 . Conclusion: I-PA was considered a valid and reliable questionnaire measuring incontinence quality of life in the aspect of praying ability or spirituality among Muslim childbearing-aged women.

Keywords: Validity, Reliability, Exploratory factor analysis, Incontinence praying ability, Incontinence, Quality of life

CORRESPONDING AUTHOR Yee Cheng Kueh (PhD), Unit of Biostatistics and Research Methodology, School of Medical Sciences, Universiti Sains Malaysia, 16150 Kubang Kerian, Kelantan, Malaysia | Email: yckueh@usm.my 


\section{INTRODUCTION}

Urinary incontinence (UI) is not a disease, but rather a symptom resulting from impairment of the bladder or of the sphincter mechanism (1). Commonly, UI was defined as a condition of involuntary leakage of urine. It is an inability to hold urine in the bladder because voluntary control over the urinary sphincter is either lost or weakened. This condition of UI can be defined as any involuntary loss of urine and can occur in all ages for many different reasons (2).

UI is a common chronic condition that affects people of all ages (3). Commonly, this condition of UI was recognised as a major health problem for women and was a widespread health problem and affecting $10 \%-50 \%$ of women during their lifetimes (4). Buckley and Lapitan had reported that the prevalence rates of UI among men are less than women by ratio one to two (2). UI was reported as an important health problem with psychological, social and hygienic effects on life of both women and their families (5). Previous studies showed that UI will affect substantial debility, social seclusion, psychologic stress and economic burden (6).

The assessment of quality of life (QoL) becomes important since Broome stated that women with UI tend to report a poorer QoL (7). Corcos et al. also stated that the assessment of QoL can be useful outcomes in benign diseases like UI (1). Besides, the assessment of impact of UI towards QoL has been widely used in patients with UI problem and has proved to be appropriate outcome measures (1).

Besides QoL assessment among patients with UI problem, Dariah in her previous study stated that the assessment of praying ability among women with UI was crucial since the majority of Malaysia population are Muslim (8). Furthermore, Muslim women with UI problem may face difficulties to perform prayer due to UI that could impact their QoL (9). Due to this reason, Dariah had developed new instrument of Incontinence Praying Ability (I-PA) to assess the impact of UI towards praying ability. This set of questionnaire will focus on QoL of Muslim women in aspect of performing prayers (8). Since the questionnaire was new developed instrument, the validation of this instrument became crucial and essential.

There was no established questionnaire that specifically measured the QoL of Muslim women in aspect of performing prayers. It was hoped that validation of the I-PA may serve as the psychometrically sound tool for measuring the QoL of Muslim women with childbearing age, specifically on the aspect of performing prayers. The present study aimed to explore the validity and reliability of the new developed instrument of I-PA among Muslim women under childbearing age who attended Hospital Universiti Sains Malaysia (HUSM).

\section{METHODS}

\section{Study Design, Setting and Population}

Study design for the present study was cross-sectional. Reference Population in this study was Muslim women under childbearing age and Source Population was women who attended particular clinics includes obstetrics and gynecology clinic, outpatient clinic, specialist clinic and staff clinic at HUSM. The participants must met the inclusion criteria and there were: Childbearing women with age between 18 until 45 years old, a Muslim women, experienced UI problem, and a patient that attended particular clinics at HUSM to get treatment, follow-up treatment or medical check-up.

\section{Incontinence Praying Ability (I-PA)}

I-PA scale was new developed questionnaire by Dariah (8). This questionnaire was developed by adapting the design of I-QoL questionnaire. The original construction 
of I-PA model was in English-version with eight items under one factor of prayer ability or spiritual and used five-point likert scale, ranged from 1 to 5 . Then, the questionnaire was finalized into Malay-version with two addition items were added in. Thus, there were total 10 items for I-PA construct, and theoretically all the items should belong to one factor. I-PA questionnaire is shown in Appendix.

\section{Incontinence Quality of Life (I-QoL)}

I-QoL was an established questionnaire developed by Patrick et al. (10). This established questionnaire was then translated into Malay-version by Dariah in her previous study (8). The translated I-QoL, Malay-version was used in this study to compare with the new established measure, I-PA. The questionnaire involved three factors with 22 items and used fivepoint likert scale, ranged from 1 to 5 . The factors were Avoidance and Limiting Behaviour (ALB), Psychosocial Impacts (PI) and Social Embarrassment (SE). The internal consistency (Cronbach alpha) of the subscales was ranged 0.91 to 0.96 and test-retest stability with ICC ranged from 0.72 to 0.97 based on a cross-cultural study conducted by Bushnell et al. (11).

\section{Procedures}

Non-probability sampling method of purposive was applied in this study. The study was conducted between November 2015 and March 2016. The self-administered questionnaire pack was distributed to the eligible Muslim women under childbearing age during their visit to their appointed clinic. Participants were briefed about the study, the procedures, and the confidentiality of their responses. If they agreed to participate, they would complete and returned the questionnaire to the researcher. The time to complete the questionnaire was approximately 15 minutes.

\section{Data Analyses}

All data analyses were conducted using IBM Statistical Package for Social Sciences (SPSS), version 24. Preliminary data analysis was done to investigate the missing value, outlier and normality distribution of the collected data. Exploratory Factor Analysis (EFA) was conducted to examine the construct validity of I-PA. Several assumptions and requirements were checked in EFA. Multicollinearity among items of I-PA was assessed through Variance Inflation Factors (VIF). Positive definiteness by using extraction method of Principal Components Analysis (PCA) was assessed based on eigenvalues with more than zero. KaiserMeyer-Olkin (KMO) was used to determine whether the items are worth to be factorised and cut-off point of KMO more than 0.7 was used as guideline (12). A significant test of Bartlet's test of Sphericity indicated that there were worthwhile correlations among the items based on correlation matrix, thus warrant for a factor analysis (13). Principle Axis Factoring (PAF) was used to extract the factors. Initial eigenvalues and scree plot were examined to identify possible number of factors for I-PA. Once the number of factors was identified, EFA was re-run again by fixing the number of factors. Items with poor loading $(<0.50)$, cross loading problem, and low communalities value $(<0.50)$ were treated as problematic items (14). Decision of removing the problematic item was made after adequate theoretical support was carried out by the researchers. In case of more than one factor extracted, obliques rotation would be used to produce a solution with the best simple structure. Factor rotation was not applicable when only one factor was extracted. After the number of factor was identified in EFA, internal consistency reliability of I-PA was examined based on Cronbach's Alpha. Then, Pearson correlation was used to examine the correlation between I-PA and subscales of I-QoL (i.e., ALB, PI and SE). 


\section{Ethical Issues}

Ethical approval and permission to conduct the study was obtained from the Human Research Ethics Committee, Universiti Sains Malaysia (Ethics reference number: USM/JEPeM/[265.4(1.6)]). Participants were informed and written consent was obtained before they were included in the study.

\section{RESULTS}

\section{Data Screening, Assumptions Checking and Sample Characteristics}

A total of 162 childbearing Muslim women completed the questionnaire and returned it to the researcher. On data screening, no missing data was found. Data on each item in I-PA were mildly skewed to the left based on visual assessment on the histograms. All the participants were married and had experience on pregnancy. The descriptive statistics participants' characteristics were summarised in Table 1.

Table 1: Descriptive statistics of socio-demographic characteristics

\begin{tabular}{|c|c|c|}
\hline Variables & $n(\%)$ & Mean (SD) \\
\hline \multicolumn{3}{|l|}{ Clinic } \\
\hline Obstetrics and gynecology & $102(63.0)$ & \\
\hline Outpatient & $28(17.3)$ & \\
\hline Specialist & $17(10.4)$ & \\
\hline Staff & $15(9.3)$ & \\
\hline Age & & $32.4(5.87)$ \\
\hline \multicolumn{3}{|l|}{ Race } \\
\hline Malay & $156(96.2)$ & \\
\hline Chinese & $3(1.9)$ & \\
\hline Others & $3(1.9)$ & \\
\hline No. of children & & $2.2(1.85)$ \\
\hline \multicolumn{3}{|l|}{ Educational level } \\
\hline Primary school & $4(2.5)$ & \\
\hline Secondary school & $68(42.0)$ & \\
\hline Diploma & $40(24.6)$ & \\
\hline Bachelor & $44(27.2)$ & \\
\hline Master & $4(2.5)$ & \\
\hline $\mathrm{PhD}$ & $2(1.2)$ & \\
\hline
\end{tabular}


Table 1: (continued)

\begin{tabular}{lcc}
\multicolumn{1}{c}{ Variables } & $\boldsymbol{n}(\%)$ & Mean (SD) \\
\hline Job status & $94(58.0)$ \\
Work & $66(40.7)$ \\
Housewife & $2(1.3)$ \\
Student & \\
\hline Household income & $16(9.9)$ \\
Less than RM1000 & $58(35.8)$ \\
RM1000 until RM2000 & $27(16.7)$ \\
RM2000 until RM3000 & $23(14.2)$ \\
RM3000 until RM4000 & $38(23.5)$ \\
More than RM4000 & $4.3(1.87)$ \\
\hline Number of family member
\end{tabular}

\section{EFA and Internal Consistency of I-PA}

Several assumptions and requirements were checked in the EFA. There was no multicollinearity problem since the VIF were less than 10 for all 10 items of I-PA. Positive definiteness was satisfied with all eigenvalues more than zero. The KMO value was 0.90 which indicated that the items were meaningful to be factorised. The Bartlett test of Sphericity produced was significant $(p<0.001)$ which indicated meaningful correlation among the items.

Based on the initial Eigenvalues (see Table 2) and observation on scree plot (see Figure 1), two factors were identified for I-PA.

EFA was re-ran by fixing number of factor to two as suggested in the initial analysis. There were no items with factor loading less than 0.5 and communalities values less than 0.5 (see Table 3). However there was an item exceeding high factor loading of 1.02 .
The two factors model of I-PA was checked by the researchers and the experts. During the development of I-PA, one factor with 10 items was considered theoretical sound and important. The two factors model identified in the EFA was investigated and researchers decided that one factor model was more appropriate than two factors model. Therefore, EFA was repeated by restricting number of factor to one. Results showed that all items loaded into one factors adequately well with factor loadings ranged from 0.70 to 0.91 and communalities ranged from 0.50 to 0.83 (see Table 4). All the 10 items were remained in this model under one factor as no deletion was required. The reliability test on I-PA one factor model was satisfactory with Cronbach's alpha of 0.94 . 


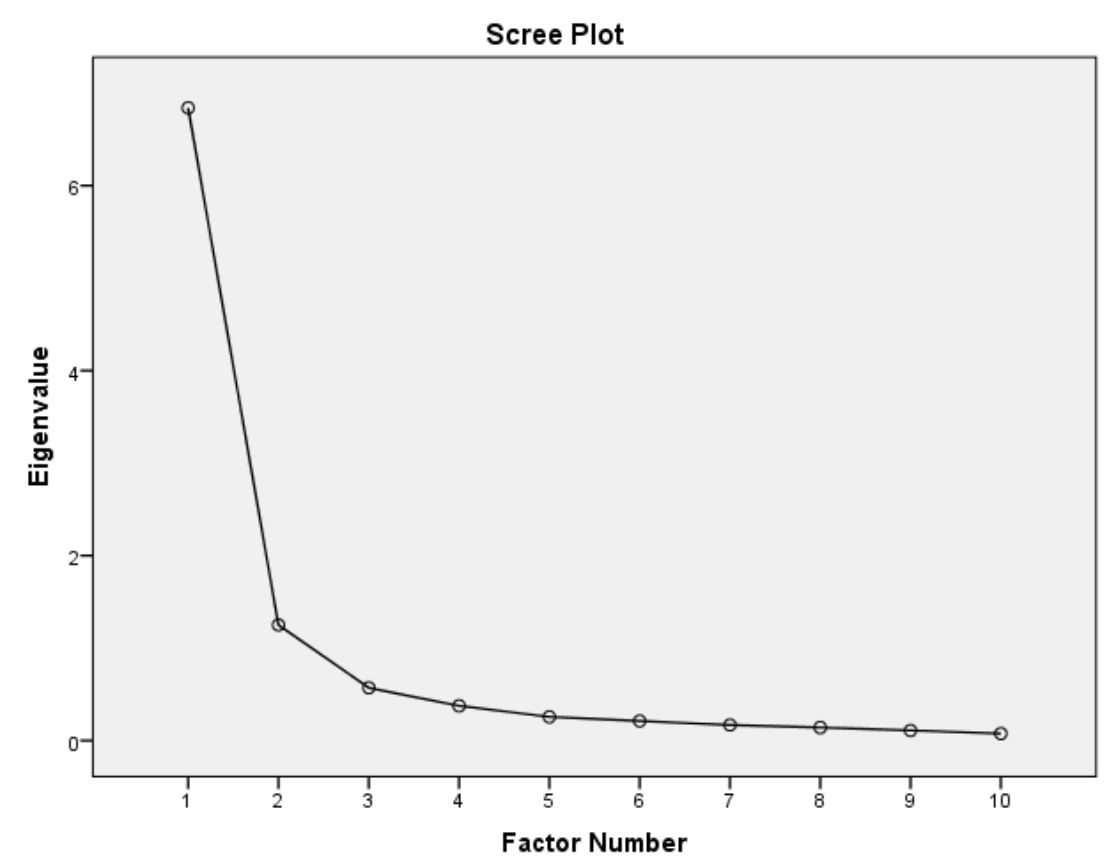

Figure 1: Scree plot of I-PA

Table 2: Initial eigenvalues of I-PA

\begin{tabular}{cccc}
\hline \multirow{2}{*}{ Factor } & \multicolumn{3}{c}{ Initial eigenvalues } \\
\cline { 2 - 4 } & Total & \% of variance & Cumulative \% \\
\hline 1 & 6.84 & 68.41 & 68.41 \\
2 & 1.25 & 12.50 & 80.91 \\
3 & .57 & 5.71 & 86.62 \\
4 & .38 & 3.76 & 90.38 \\
5 & .26 & 2.56 & 92.94 \\
6 & .21 & 2.12 & 95.06 \\
7 & .17 & 1.68 & 96.74 \\
8 & .14 & 1.41 & 98.15 \\
9 & .11 & 1.10 & 99.24 \\
10 & .08 & .76 & 100.00 \\
\hline
\end{tabular}


Table 3: Factor loadings and communalities of I-PA model with two factors

\begin{tabular}{cccc}
\hline \multirow{2}{*}{ Items } & \multicolumn{2}{c}{ Factor loadings } & $\begin{array}{c}\text { Communalities } \\
\text { (extraction) }\end{array}$ \\
\cline { 2 - 3 } Factor $\mathbf{1}$ & Factor $\mathbf{2}$ & 0.76 \\
P1 & & 0.90 & 0.87 \\
P2 & & 1.02 & 0.80 \\
P3 & & 0.85 & 0.81 \\
P4 & & 0.52 & 0.70 \\
P5 & 0.73 & & 0.86 \\
P6 & 0.83 & & 0.90 \\
P7 & 0.91 & & 0.61 \\
P8 & 0.65 & 0.67 \\
P9 & 0.95 & 0.69 \\
P10 & 0.88 & & \\
\hline
\end{tabular}

Note: P1 to P10 represented the items in the questionnaire, I-PA.

Table 4: Factor loadings and communalities of I-PA model with one factor

\begin{tabular}{cccc}
\hline Items & Factor loadings & $\begin{array}{c}\text { Communalities } \\
\text { (extraction) }\end{array}$ & $\begin{array}{c}\text { Cronbach's } \\
\text { alpha }\end{array}$ \\
\hline P1 & 0.73 & 0.54 & \\
P2 & 0.74 & 0.54 & \\
P3 & 0.78 & 0.62 & \\
P4 & 0.90 & 0.80 & \\
P5 & 0.83 & 0.68 & \\
P6 & 0.91 & 0.83 & \\
P7 & 0.90 & 0.82 & \\
P8 & 0.78 & 0.61 & \\
P9 & 0.70 & 0.50 & \\
P10 & 0.77 & 0.59 & \\
\hline
\end{tabular}

Note: P1 to P10 represented the items in the questionnaire, I-PA. 


\section{Correlation between I-PA and I-QoL}

There were significant correlation between I-PA and subscales of I-QoL (see Table 5). Theoretically, higher level of prayer ability or spiritual, the QoL would be higher as well among childbearing Muslim women with UI. The correlations were ranged from 0.64 to 0.71 and all were statistically significant. Thus, these findings further support the validity of I-PA.

Table 5: Correlation between I-PA and I-QoL's subscales

\begin{tabular}{cccc} 
Factors & Mean(SD) & I-PA & $p$-value \\
\hline ALB & $3.77(0.91)$ & 0.64 & $<0.001$ \\
PI & $4.17(0.91)$ & 0.69 & $<0.001$ \\
SE & $3.91(0.99)$ & 0.71 & $<0.001$ \\
I-PA & $4.01(0.97)$ & - & - \\
\hline
\end{tabular}

Notes: $\mathrm{ALB}=$ Avoidance and Limiting Behaviour; $\mathrm{PI}=$ Psychosocial Impacts; $\mathrm{SI}=$ Social Embarrassment (SE); $\mathrm{I}-\mathrm{PA}=$ Incontinence Praying Ability

\section{DISCUSSION}

The purpose of this study was to explore the construct validity of new developed questionnaire, namely I-PA, used among Muslim women with UI problem. The questionnaire was developed in a study conducted by Dariah (8). The content and face validity had been established in the previous study (8). The present study employed EFA to further explore the validity of the I-PA. EFA was required in order to explore the items and extract the common idea of the instrument as well as to generate theory based on the empirical findings. Overall the results indicated that the best model for I-PA measure was based on one factor model. One factor model of I-PA was theoretically sound and results of EFA were satisfactory. There were no items removed in the EFA analyses. All items are deemed important in measuring the QoL in the aspect of prayer ability or spiritual. I-PA was regarded as spiritual scale since the items developed under the construct measure the aspect of praying ability.

Measurement reliability of I-PA model was assessed via internal consistency reliability of Cronbach's alpha method. This measurement reliability will assessed how homogenous the items in a construct in term of their variance (15). Based on the result, the value of Cronbach's alpha of I-PA model showed good scale reliability for the construct measured. Cronbach's alpha for 'spiritual' was 0.94 which indicated a good reliability. For Cronbach's alpha, usually it should be more than 0.6 or 0.7 for an acceptable internal consistency $(15,16)$. Some researchers reported that the acceptable values of Cronbach's alpha, ranging from 0.70 to $0.95(17,18,19)$. If Cronbach's alpha value is too high it may indicate that some items are redundant as they have a same content but in a different guise (20). In the present study, we can conclude that the Malay-version of I-PA model had good construct reliability among Muslim women with childbearing age based on the value of Cronbach's alpha.

Since I-PA was new developed instrument and I-QoL was an established instrument, the validity was also assessed by observing the correlations between both instruments after construct validity and reliability of I-PA were identified. Significant correlation found between I-PA and I-QoL's subscales further support the validity of I-PA. I-PA was showed to be highly significant correlated with all three components of I-QoL, namely avoidance and limiting behaviour, psychosocial impacts and social embarrassment. The instrument of I-PA was developed to measure the QoL specifically 
on spiritual routine (prayer ability) among Muslim patients with UI problem. Thus, theoretically I-PA should be highly correlated with the established instrument of I-QoL among patients with UI problem. Therefore, this study further supports the validity of I-PA among Muslim women with childbearing age.

Several limitations were noted during the entire process of this study. First, participants involved in this study were general population of childbearing women that involved both pregnant and non-pregnant women at the time of data collection. Information bias might happen because participants may face UI problem due to pregnancy. However, due to limited time and resources to conduct this study, to assessed the validation of the I-PA instrument among Muslim nonchildbearing-age women only seem to be challenging as validation study required relatively big sample size. Second, I-PA was only assessed among Muslim childbearingaged women and the majority of them were Malay. Since Malaysia population involves variety of ethnics, the assessment of Muslim women in other ethnics is crucial. However, to involve other ethnics Muslim women was problematic since the majority of patients that had attending the HUSM were Malay. Therefore, future research should include validation of I-PA among non-childbearing age Muslim women, Muslim male and more proportion of participants from other Muslim ethnics group in Malaysia.

\section{CONCLUSION}

This study was the first study to validate the new developed instrument of I-PA in Malay language, which is deemed important for our Muslim community in Malaysia. Despite the limitations, we provided the evidence of validity for the new developed measure of I-PA. The scale showed good validity and reliability among Muslim childbearing-aged women who attended HUSM. Since praying ability becomes crucial aspect among Muslim, it is recommended to include I-PA in QoL assessment among patients with UI problem. Hence, the QoL assessment among Muslim can be assessed specifically in the aspect of their spiritual routine in Malaysia population.

\section{ACKNOWLEDGEMENTS}

This research was supported by a short-term grant from the Universiti Sains Malaysia (304/PPSK/61313019). We would like to thank the patients who gave their time to complete the survey.

\section{REFERENCES}

1. Corcos J, Beaulieu S, Donovan J, Naughton M, Gotoh M. Quality of life assessment in men and women with urinary incontinence. J Urol. 2002;168(3):896-905. https://doi. org/10.1097/01.ju.0000024401.79394.21

2. Buckley BS, Lapitan MC. Prevalence of urinary incontinence in men, women, and children-current evidence: findings of the Fourth International Consultation on Incontinence. Urology. 2010;76(2):26570. https://doi.org/10.1016/j.urology.2009. 11.078

3. Minassian VA, Stewart WF, Wood GC. Urinary incontinence in women: variation in prevalence estimates and risk factors. Obstet Gynecol. 2008;111(2):324-31. https://doi. org/10.1097/01.AOG.0000267220.48987.17

4. Monz B, Chartier-Kastler E, Hampel C, Samsioe G, Hunskaar S, Espuna-Pons M, et al. Patient characteristics associated with quality of life in European women seeking treatment for urinary incontinence: results from PURE. Eur Urol. 2007;51(4):1073-81. https://doi.org/10.1016/j.eururo.2006.09 .022 
5. Kocak I, Okyay P, Dundar M, Erol H, Beser E. Female urinary incontinence in the west of Turkey: prevalence, risk factors and impact on quality of life. Eur Urol. 2005;48(4):634-41. https://doi.org/10.1016/j .eururo.2005.04.017

6. Nojomi M, Amin EB, Rad RB. Urinary incontinence: hospital-based prevalence and risk factors. J Res Med Sci. 2008;13(1):22-8.

7. Broome BA. The impact of urinary incontinence on self-efficacy and quality of life. Health Qual Life Outcomes. 2003;1(1): 35. https://doi.org/ 10.1186/1477-7525-1-35.

8. Dariah MY. Postnatal urinary incontinence in Kelantan, Malaysia: a mixed methods study. (PhD Dissertation). Adelaide: Flinders University Adelaide Australia; 2011.

9. El-Azab AS, Mohamed EM, Sabra HI. The prevalence and risk factors of urinary incontinence and its influence on the quality of life among Egyptian women. Neurourol Urodyn. 2007;26(6):783-88. https://doi. org/10.1002/nau.20412

10. Patrick D, Martin M, Bushnell D, Yalcin I, Wagner T, Buesching D. Quality of life of women with urinary incontinence: further development of the incontinence quality of life instrument (I-QOL). Urology. 1999;53(1):71-6.

11. Bushnell DM, Martin ML, Summers KH, Svihra J, Lionis C, Patrick DL. Quality of life of women with urinary incontinence: cross-cultural performance of 15 language versions of the I-QOL. Qual Life Res. 2005;14(8):1901-13. https://doi. org/10.1007/s11136-005-5266-5.
12. Kaiser HF, Rice J. (1974). Little Jiffy, Mark IV. Edu Psychol Meas. 1974;34:111-7.

13. Williams B, Brown $\mathrm{T}$, Onsman A. Exploratory factor analysis: a five-step guide for novices. Australasian Journal of Paramedicine. 2012;8(3). Available from: http://ro.ecu.edu.au/jephc/vol8/iss3/1.

14. Hair JF Jr, Black WC, Babin BJ, Anderson RE. Multivariate data analysis. 7th ed. New Jersey: Pearson Prentice Hall; 2010.

15. Kline RB. Principles and practice of structural equation modeling. 3rd ed. New York: The Guilford Press; 2011.

16. George D, Mallery P. SPSS for Windows step by step: a simple guide and reference 11.0 update. 4th ed. Boston: Allyn \& Bacon; 2003.

17. Nunnally J, Bernstein L. Psychometric theory. New York: McGraw-Hill Higher, Inc.; 1994.

18. Bland J, Altman D. Statistics notes: Cronbach's alpha. BMJ. 1997;314:575. https://doi.org/10.1136/bmj.314.7080.572.

19. DeVellis R. Scale development: theory and applications. Thousand Oaks, CA: Sage; 2003.

20. Tavakol M, Dennick R. Making sense of Cronbach's alpha. Int J Med Educ. 2011;2: 53-5. https://doi.org/10.5116/ijme.4dfb.8dfd 


\section{Appendix}

\section{Incontinence Praying Ability -- I-PA (Malay language)}

\section{KESAN MASALAH MENGAWAL KENCING TEHADAP KEUPAYAAN BERSOLAT}

Berikut adalah kenyataan yang berkaitan dengan kesan masalah kencing tidak terkawal terhadap keupayaan pengidapnya melakukan wuduk dan bersolat.

Arahan: Sila tandakan (P) di kotak yang berkenaan bagi menggambarkan keadaan anda mengenai kesan masalah kencing tidak terkawal.

\begin{tabular}{|c|c|c|c|c|c|c|}
\hline Bil. & $\begin{array}{c}\text { Kesan masalah kencing tidak terkawal } \\
\text { terhadap keupayaan melakukan } \\
\text { wuduk dan bersolat }\end{array}$ & $\begin{array}{l}\text { Sangat } \\
\text { banyak }\end{array}$ & Banyak & Sederhana & Sedikit & $\begin{array}{l}\text { Langsung } \\
\text { tiada kesan }\end{array}$ \\
\hline 1. & $\begin{array}{l}\text { Saya merasa risau samada saya sudah } \\
\text { betul-betul bersih setiap kali hendak } \\
\text { mengerjakan solat kerana masalah tidak } \\
\text { boleh mengawal kencing saya ini. }\end{array}$ & & & & & \\
\hline 2. & $\begin{array}{l}\text { Saya perlu menukar kain/seluar yang saya } \\
\text { pakai setiap kali bersolat kerana masalah } \\
\text { tidak boleh mengawal kencing saya ini. }\end{array}$ & & & & & \\
\hline 3. & $\begin{array}{l}\text { Saya akan mandi tiap kali sebelum } \\
\text { mengerjakan solat kerana masalah tidak } \\
\text { boleh mengawal kencing saya ini. }\end{array}$ & & & & & \\
\hline 4. & $\begin{array}{l}\text { Saya mengulangi wuduk saya beberapa } \\
\text { kali sebelum solat kerana masalah tidak } \\
\text { boleh mengawal kencing saya ini. }\end{array}$ & & & & & \\
\hline 5. & $\begin{array}{l}\text { Saya terus bersolat walaupun saya sedar } \\
\text { saya akan terkencing lagi pada bila-bila } \\
\text { masa. }\end{array}$ & & & & & \\
\hline 6. & $\begin{array}{l}\text { Saya tidak kusyuk semasa bersolat kerana } \\
\text { masalah tidak boleh mengawal kencing } \\
\text { saya ini. }\end{array}$ & & & & & \\
\hline 7. & $\begin{array}{l}\text { Saya mengulangi solat saya beberapa kali } \\
\text { kerana masalah tidak boleh mengawal } \\
\text { kencing saya ini. }\end{array}$ & & & & & \\
\hline 8. & $\begin{array}{l}\text { Saya merasa berdosa kerana terus } \\
\text { mengerjakan solat walaupun dalam } \\
\text { keadaan yang kurang bersih/berbau } \\
\text { kerana masalah tidak boleh mengawal } \\
\text { kencing saya ini. }\end{array}$ & & & & & \\
\hline 9. & $\begin{array}{l}\text { Saya kerap meninggalkan solat kerana } \\
\text { masalah tidak boleh mengawal kencing } \\
\text { saya ini. }\end{array}$ & & & & & \\
\hline 10. & $\begin{array}{l}\text { Saya merasa solat saya seakan tidak } \\
\text { diterima oleh Tuhan kerana masalah tidak } \\
\text { boleh mengawal kencing saya ini. }\end{array}$ & & & & & \\
\hline
\end{tabular}

